\title{
THE USE OF GOOGLE CLASSROOM IN ENGLISH TEACHING AND LEARNING PROCESS AT SENIOR HIGH SCHOOL LEVEL
}

\author{
Herlia Nursyahrina ${ }^{1^{*}}$ \\ Lady H. Retami ${ }^{2}$ \\ Rika Pratama ${ }^{3}$ \\ Syahla Putri Salsabil ${ }^{4}$ \\ Muhammad Taufik Ihsan ${ }^{5}$ \\ 1,2,3,4,5 Departement of English Education, Faculty of Education and Teacher Training \\ State Islamic University of Sultan Syarif Kasim Riau, Indonesia \\ herlianursyahrina@gmail.com $^{1 *}$ \\ ladyretami@gmail.com ${ }^{2}$ \\ pratamarika533@gmail.com ${ }^{3}$ \\ syahlaputriyaya21@gmail.com ${ }^{4)}$ \\ muhammad.taufik.ihsan@uin-suska.ac.id $\left.{ }^{5}\right)$
}

\begin{abstract}
The Covid-19 pandemic requires almost all human activity to move to digital media, including education services. Recently, education services must adapt to online learning methods. In response to these changes, many states, institutions, and organizations have been working on strategic plans to implement online education. The objective of this paper was to describe the usage of google classroom in the English teaching and learning process at the senior high school level. The method used in writing this paper was literature-based by collecting data and information that related to Google Classroom as a media for learning the English language. The results indicated that there are many advantages of using Google Classroom in implementing education in Indonesia are to enhance teachers' and students' ability to use technology wisely, particularly for learning processes, to save time, to be environmentally conscious, to overcome the distance of residence, to increase collaboration among students, to provide timeless communication, and to serve as secure document storage.
\end{abstract}

Keywords: Technology, Google Classroom, English Teaching and Learning.

Published by:

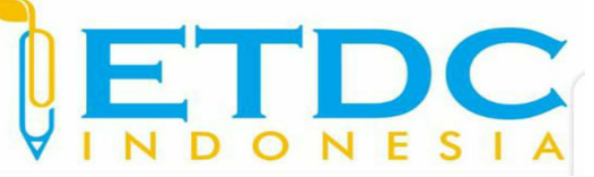

Copyright (C) 2021 The Author (s)

This article is licensed under CC BY 4.0 License

$(\mathrm{cc}) \mathrm{EY}$ 


\section{THE USE OF GOOGLE CLASSROOM IN ENGLISH TEACHING AND LEARNING PROCESS AT SENIOR HIGH SCHOOL LEVEL}

\section{Introduction}

When questioned about essential items in his life, a student stated, "Technology is a part of my life." Most of the students agreed with this notion when they finally expressed how technology had sparked their interest. They typically used it for recreational purposes, such as playing online games, conversing on social media, surfing information, and other enjoyable activities.

This occurrence, which primarily occurs in certain parts of the world, cannot be dismissed, especially given how far technology has advanced in recent years. Students are clearly surrounded and aided by computers, the internet, smartphones, and other types of technology, all of which have an impact on their social and scholastic lives (Simuforosa, 2013).

Their dependency on technology alters their learning practices, causing them to become bored easily when a teacher just talks without using visual pictures or supplies them with printed materials. Given this situation, there is a significant chance to alter the teaching style away from traditional methods and toward technological integration.

Technology has been shown to improve students' active involvement and learning results, according to Kuh \& $\mathrm{Hu}$ (2001). In contrast to the traditional strategy, which requires students to become passive learners, students become more active to participate in the learning activity. Lately, there have been many applications that are easy to use for teachers and students. Teachers and students, as well as school stakeholders, recognize the value of learning technology (Stošić, 2015).

Google Classroom has become one of the most widely utilized teaching platforms among professors and students. Over 30 million assignments had been uploaded by professors and students to Google Classroom. It suggests that this program could be a useful tool for teaching and learning in our educational system (Iftakhar, 2016).

Google Classroom is a web-based course management system (CMS). It provides a setting for instructional delivery and learning procedures in which students gain knowledge through conversation, interaction, and discussion. Teachers can use this platform to offer their courses, and students can be assigned to upload tasks and other assignments. In this way, Google Classroom helps teachers and lecturers to create and organize assignments, comments, and communicate with their classes. (Shaharanee, Jamil, \& Rodzi, 2016b). 
A study found that Google Classroom is an acceptable LMS (Learning Management System) application because it is already linked to the university and school systems and appears to match students' requests for a simpler interface that allows for more engagement (Heggart \& Yoo, 2018). The students simply require the class code from their professors or lecturers. Then, once they have the code, they can access Google Classroom. After that, students will be successfully registered in the class. Educators and students can also engage in active participation in the application. For each activity set by the educators, Google Classroom provides capabilities that allow both educators and students to communicate in groups or privately.

Furthermore, Google Classroom can provide students with a novel learning environment (Shaharanee et al., 2016a). Because the students and the educator will not be able to see each other immediately, it may prompt them to inquire further about the lesson taught in the application. They can also talk about the responses to their friends' inquiries. The educator will be in charge of the students' questions and answers. It means that if students deviate from the intended path, the educator can redirect them to the correct path. It goes without saying that by incorporating Google Classroom into English classes, students will have more time and space to work at their own pace.

As a free tool, Google Classroom provides students to be independent, engaged and motivated as most young learners tend to use technology in their daily lives. It also makes the teaching and learning process successful in the digital era such as the industrial revolution 4.0 which is demanded by teachers of expertise, the ability to adapt to new technology, and global challenges. Therefore, the researchers felt interested to looks at how Google Classroom is used in the English teaching and learning process at the senior high school level.

\section{Methodology}

This article is literature-based in which the data and information were gathered from the book, internet postings, journal, etc. Literature studies in research, according to Arikunto (2006), are a means of gathering data by searching for material in books, newspapers, periodicals, and other forms of literature in order to provide a theoretical foundation. Along with this opinion, according to Nazir (1988), A literature study is a data collection approach that involves performing study studies of books, literature, records, and reports that have to do with problems solved. There are some points that will be discussed in this article. The first one is about Google Classroom's Definition. All about the definition of Google Classroom will be analyzed through journal articles that can be accessed online. Furthermore, the second issue 
that is carried out was the process of teaching and learning by using Google Classroom. All relevant articles are used to analyze this issue. Moreover, The Use of Google Classroom to Assist the Teaching and Learning Process is discussed in this article. In order to get a clearer explanation related to these topics, the researcher also analyzes some related documents that can be used to explain these issues.

\section{Discussion}

\section{a. Definition of Google Classroom}

Google describes Google Classroom as "mission control for your classroom," which might be the easiest way to think about it. Google Classroom is a free, internet-based collaboration tool developed by Google as part of G Suite for Education for creating, distributing, and grading assignments. With a Google account, educators can use the platform to create a virtual classroom, invite students to attend live instruction and record students' grades.

Google Classroom is a free online classroom application that allows students and teachers to collaborate. Teachers may also create and deliver assignments to students (Beal, 2017). This application is very easy to use, takes up little space on the smartphone's memory, and assists both the teacher and the student in staying on track with the lesson. This application allows teachers to easily create groups in which they may share assignments and announcements.

Google Classroom has the potential to turn students into active participants. According to Nagele (2017), teachers may utilize Google Classroom to create active lessons that are student-centered, collaborative, and memorable since it offers simple learning elements and allows students of various types to collaborate.

Google Classroom is beneficial to all types of learners, even adults. Google classroom is flexible in use. Google Classroom can be accessed anywhere and anytime as long as there is an internet connection. Users can access it when they are at home, even on the way because mobile phones facilitate them to operate this tool. Having Google Classroom for learning can build social integration. When the students use Google Classroom, they communicate with the teacher and another student online through Google Classroom.

Google Classroom is environmentally friendly. Since technology is an online tool, it helps teachers to manage the creation and collection of student assignments in a paperless setting. Google Classroom is utilized not only for online learning but also for supporting media to aid teachers in delivering assignments or tasks (Sholah, 2020). Here, teachers and students 
can upload the file. Then, the files are organized well. All submitted files are online and organized in Google Classroom safely. Then, teachers can give feedback on the students' work. It is extremely advantageous to both teachers and students due to its ease of usage.

According to S. Iftakhar, Google Classroom allows teachers to spend more time with their students and less time on paperwork, and it is now even better. Google Classroom has gained new features as a result of Google's latest announcement. The option to add more than one teacher, as well as the option to prepare for classes in advance, are all part of the new capabilities. (2016, p. 12-13)

As M. Janzen points out below, Google Classroom is a simple application to use: The instructional interface and methods for delivering and tracking assignments are purposely streamlined in Google Classroom; communication with the entire course or individuals is likewise simplified through announcements, email, and push notification (2017).

One of Google Classroom's biggest strengths is that it is easy to access and promotes communication with students and teachers. Teachers will create a class and list education tasks with just a few taps, such as assignments. Created assignments can be posted immediately, saved as a draft, or scheduled to post later. Students receive an email notification when new assignments are created, complete the assignment, then submit it. Students can also attach additional documents from the Drive to the assignment. Google Classroom also allows the teacher to see which students have completed their assignments and the teacher can provide direct, real-time feedback and grades. Google Classroom essentially puts all of your assignments, announcements, and student work right in one place.

Google Classroom has numerous facilities, including: (1) User friendly: It is very easy to use, (2) Cloud-based: Google Classroom offers more professional and authentic technology to use in a learning environment, (3) Cost-free: It does not require any cost to use it, (4) Cell phone friendly: It is convenient to be used on any mobile device, (5) Time-saving: Google Classroom saves time both in teachers' and students' parts, (6) Vast range of resources: Google Classroom could be connected to a vast range of learning portals on the internet, and (7) Centralized Data Storage: With Google Classroom, all participants including students and lecturers are located in one centralized location.

Despite various advantages, there are some limitations of Google Classroom, including: (1) Limited integration options, (2) Too "googlish": It is equipped with several buttons which are familiar to Google users only, (3) No automated updates: Google Classroom does not take the update on activity-feeds automatically. (4) Difficult learner sharing: Sharing a document with other classmates is impossible if a student does not become the owner of a document, (5) 
Editing problems: After creating and distributing assignments, learners become owners of the document. As an owner, they are given the authority to edit it. Eventually, they can delete any part of the assignment if they want, (6) No automated quizzes and tests: Google Classroom has no provision for automated quizzes and tests, and (7) Impersonal: there is no way to have a live chat in Google Classroom; at least, not yet.

Google Classroom is very easy to use, the first thing the teacher needs to do is of course open the Google Classroom application on their device (classroom.google.com). Then, to create your first class, click the "+" button. This "+" button is located next to your email address. Then select "Create Class" from the drop-down menu. Then, Include a class name and a section, such as "EFL Instruction and Multimedia - 6F Class". On the "About" page, you may enter information about your class. You can provide a description of the class as well as for instructions for the students. Students can now enter the classroom. Request that they use their personal Google accounts to access Google Classroom. They must click the "+" button, which will prompt them for a class code. Find your class code under the "Stream" page and provide it to your students so they may join your class.

\section{b. Teaching and Learning Process}

Google Classroom allows users, both instructors and students, to exchange resources, assignments, quiz questions, and even connect to one another. From his or her smartphone, the instructor may simply control the class. There is no longer a need for paper for assignments, notes, or tests. Students can complete the assignment and submit it in the application to the folder supplied by the teacher.

The teacher can make an announcement and offer a Google Classroom task for the class to complete. The file formats that may be supplied in this application are likewise diverse. Any file format is acceptable, including doc, pdf, ppt, $\mathrm{xl}, \mathrm{jpg}, \mathrm{mp} 3$, and even mp4. This service is very beneficial for language classes. Language classes cover both verbal and written communication abilities. As a result, Google Classroom is an excellent choice since it allows teachers to provide material and assignments, particularly audio and visual ones.

It is also effective in terms of time consumption. Unlike traditional classes, which required the teacher and students to gather in a classroom at a specific time, this program may be used at any time and from any location. There is no need to be in a specific classroom to conduct a lesson. All users require is a smartphone with an internet connection.

This program has a calendar system that allows users to keep track of class activities. The teacher may set the deadline for submitting the assignment and get notifications when students submit on time, late, or miss the deadline. This type of system is very useful for 
students to see what they need to accomplish to meet class requirements.

According to the research, Google Classroom improves the number of students who finish the class requirement satisfactorily. Students are more motivated to complete their activities since they only need to open their cellphones, see what they need to accomplish, work on it, and then submit it.

Teachers no longer have to deal with paperwork because they can verify and grade students' work from their smartphones. He or she will be notified after the student has submitted the assignment. The instructor can grade or remark on the pupils' work before returning it to them to be reviewed.

\section{c. Using Google Classroom to Assist Teaching and Learning Process}

Based on the features of Google classroom, there are some role of Google Classroom to assist teaching and learning process as follows:

1. Increased levels of educator-learner engagement

Educators can use educational applications and websites that are integrated with GC to make lessons more dynamic and engaging. Educators can construct assignments that incorporate an interactive online game, a fun YouTube movie, or a visually appealing slideshow with lots of useful information and graphics. GC engages today's technology-driven pupils by making learning enjoyable.

2. Makes teaching more focused and organized

Educators can access classwork at any time and from any location. On the move grading You may access all of your students' work and grades from anywhere using a laptop, tablet, or phone. Google Classroom also helps you keep organized by putting all of your assignments, grades, and announcements in one place. Everything is easily accessible; simply select the appropriate tab to find what you're looking for. Because everything is stored in your Classroom Drive folder and is only a click away, it's much easier to find finished assignments or a specific student's work.

3. Learner-educator communication and collaboration is made easy

Educators have the opportunity to easily ask questions and make/schedule announcements. Simply submit essential messages or queries to the class stream, and students will be able to see them as soon as they log in. Educators, students, and parents may use video conferencing programs like Google Meet to stay in touch from the comfort of their own homes or offices. If you can't meet face to face, video conferencing can help with virtual parent conferences, live classes, and Q\&A sessions.

4. Facing the Distance of the Residence

The development and utilization of ICT could be justified by improving the quality of 
Indonesian national education. Because of Indonesia's geographical location, which includes numerous scattered islands and often inhospitable earth surface contours, it is frequently recommended that the development and implementation of ICT for education that relies on distance learning abilities begin as soon as feasible.

In Indonesia, using Google Classroom to implement education is extremely helpful in conducting online education, particularly in higher education. Students can benefit from distance education by learning from lecturers who use the Google Classroom tool to teach. This online-based education necessitates each student's housing having a good signal, as well as the availability of wifi. This online-based education necessitates each student's residence having a good internet networ, wifi availability, and students having a smartphone/laptop as well as elearning learning equipment. If properly implemented, distant learning is very practical and efficient, but it does have a flaw.

5. Improving Teachers' Quality

The use of Google Classroom by educational institutions to conduct information technology-based learning will deliver the best experience for teachers in Indonesia during the learning process. Because using the Google Classroom application will have an impact on enhancing the quality of instructors in Indonesia, this learning model is one of the e-learningbased innovative learning models.

6. Improving Communication and Cooperation without Time Limit.

The teacher might send a notification to students to start an online discussion or to inform them about certain online learning activities. When discussing in Google Classroom, students have the option of immediately posting feedback to their classmates. They can get immediate feedback from virtual peers if they need assistance with an assignment or if they want to learn more about a particular topic.

The Google classroom is particularly useful for students to benefit from the experience and talents of their peers online, particularly in terms of increasing components of social learning education. Students can communicate indefinitely due to the features of the Google classroom. According to the teacher's learning plan, students can talk with their friends and seek to speak with the teacher in the morning, afternoon, evening, and night

\section{Conclusion}

Google Classroom is a component of Google Apps for Education (GAFE), a suite of productivity apps designed to assist instructors and students in learning and online collaboration. Google Classroom can be accessed via Google Chrome on any computer or from 
any mobile device, regardless of platform. On Google Drive, all files uploaded by teachers and students are saved in a Classroom folder. The classroom can be Google Classroom is a component of Google Apps for Education (GAFE), a suite of productivity apps designed to assist instructors and students in learning and online collaboration. Google Classroom can be accessed via Google Chrome on any computer or from any mobile device, regardless of platform. On Google Drive, all files uploaded by teachers and students are saved in a Classroom folder. The classroom can be accessed at any time and from any location.

The advantages of using Google Classroom in implementing education in Senior High School level Indonesia are to enhance teachers' and students' ability to use technology wisely, particularly for learning processes, to save time, to be environmentally conscious, to overcome the distance of residence, to increase collaboration among students, to provide timeless communication, and to serve as secure document storage.

In the teaching and learning process, Google Classroom allows students to collaborate in a variety of ways. Within the Classroom, teachers can organize online dialogues between students and create group projects. Additionally, students can collaborate on Google Docs that the teacher has shared. Teachers may also effortlessly differentiate education for students using Google Classroom. When generating an assignment on the Classwork page, assigning lessons to the entire class, individual students, or groups of students takes only a few simple steps.

Furthermore, providing meaningful feedback to students using Google Classroom is an important aspect of all learning. Teachers can offer feedback on tasks to each student using Classroom's grading function. Within the grading tool, you may also build a comment bank for future reference. The Classroom mobile app also allows users to annotate their work accessed at any time and from any location.

The advantages of using Google Classroom in implementing education in Senior High School level Indonesia are to enhance teachers' and students' ability to use technology wisely, particularly for learning processes, to save time, to be environmentally conscious, to overcome the distance of residence, to increase collaboration among students, to provide timeless communication, and to serve as secure document storage.

In the teaching and learning process, Google Classroom allows students to collaborate in a variety of ways. Within the Classroom, teachers can organize online dialogues between students and create group projects. Additionally, students can collaborate on Google Docs that the teacher has shared. Teachers may also effortlessly differentiate education for students using Google Classroom. When generating an assignment on the Classwork page, assigning lessons to the entire class, individual students, or groups of students takes only a few simple steps. 
Furthermore, providing meaningful feedback to students using Google Classroom is an important aspect of all learning. Teachers can offer feedback on tasks to each student using Classroom's grading function. Within the grading tool, you may also build a comment bank for future reference. The Classroom mobile app also allows users to annotate their work.

\section{REFRENCES}

Alim, N, et al. (2019). THE EFFECTIVENESS OF GOOGLE CLASSROOM AS AN INSTRUCTIONAL MEDIA: A CASE OF STATE ISLAMIC INSTITUTE OF KENDARI, INDONESIA. Humanities \& Social Sciences Reviews, 7(2).

Arikunto, S. (2006). Prosedur Penelitian Tindakan Kelas. Bumi Aksara

Brown, H. D. (2004). Principles of Language Learning and Teaching. London: Longman.

Beal, V. (2017). Google Classroom. Retrieved June 10, 2021, from Webopedia: http://www.webopedia.com/TERM/G/google-classroom.html

Heggart, K. R., \& Yoo, J. (2018). Getting the Most from Google Classroom: A Pedagogical Framework for Tertiary Educators. Australian Journal of Teacher Education, 43(3), 140153. doi:10.14221/ajte.2018v43n3.9

Iftakhar, S. (2016). Google Classroom: What works and how? Journal of Education and Social Science, 3(2), 12-18.

Joseph, B. (2020). Google Classroom and Zoom Meeting for Beginner . Lucrative Business Ideas Series.

Kuh, G. D., \& Hu, S. (2001). The relationships between computer and information technology use, selected learning and personal development outcomes, and other college Experiences. Journal of College Student Development, 42, 217-232.

M. Janzen, "Hot team: Google Classroom", Teaching and Learning with Technology, 2017. [Online]. Available: http://tlt.psu.edu/2014/12/04/hot-team-google-classroom/. Accessed: 10- June- 2021].

Mualim, M, Ma'rufah, D. W., \& Sartika, E. (2019). The Strengths and Pitfalls of Google Classroom Application to Gen-Z Students' Learning Hybridity. Proceeding of International Conference on Islamic Education: Challenges in Technology and Literacy, 4.

Muslimah, A. (2018). A SURVEY ON THE USE OF GOOGLE CLASSROOM IN ENGLISH LANGUAGE EDUCATION DEPARTMENT OF ISLAMIC UNIVERSITY OF INDONESIA.

Nagele, N. (2017). Udemy. Retrieved June 10, 2021, from Udemy.com: https://www.udemy.com/googleclassroom/ 
Nazir, M. (1988). Metode penelitian. Jakarta: Ghalia Indonesia.

Rabbi, M. M. F., Zakaria, A. K. M., \& Tonmoy, M. (2018). Teaching listening skill through Google Classroom: A study at tertiary level in Bangladesh. DUET Journal, 3(1), 2-7.

Shaharanee, I. N. M., Jamil, J. M., \& Rodzi, S. S. M. (2016a). The application of Google Classroom as a tool for teaching and learning. Journal of Telecommunication. Electronic and Computer Engineering, 8(10), 5-8.

Shaharanee, I. N. M., Jamil, J. M., \& Rodzi, S. S. M. (2016b). Google classroom as a tool for active learning. In F. A. A. Nifa, M. N. M. Nawi, \& A. Hussain (Eds.), Proceedings of the International Conference on Applied Science and Technology 2016 (ICAST'16) (Vol. 1761, pp. 020069-020066). Kedah, Malaysia: AIP Publishing.

Sholah, H. M. (2020) TEACHING AND LEARNING ENGLISH USING GOOGLE CLASSROOM FOR. Jurnal Pusaka, 8(1), 8.

S. Iftakhar. (2016). Google Classroom: What Works and How?. Journal of Education and Social Sciences, 3, 12-13.

Simuforosa, M. (2013). The impact of modern technology on the educational attainment of adolescents. International Journal of Education and Research, vol.1, no.9, pp. 1-8.

Stošić, L. (2015). The importance of educational technology in teaching. International Journal of Cognitive Research in Science, Engineering and Education, 3(1), 111-114.

Unika.ac.id. Using 'Google Classroom' App for Teaching Language. Access on 30 June 2021, from https://tinyurl.com/6d2yjxd3

Vangie, B. (2020). Google Classroom. Editor of webopedia.

Wijaya, A. (2016). Analysis of factors affecting the use of Google Classroom to support lectures. In the 5th International Conference on Information Technology and Engineering Application (ICIBA2016). 